\title{
En kvinne i 20-årene med anoreksi, hypokalemi og kramper
}

\author{
Anoreksi er en alvorlig tilstand som kan være svært vanskelig å behandle. \\ Den betydelige underernæringen griper dypt inn i kroppens fysiologiske \\ prosesser og påvirker alle organsystemer. Vi omtaler en ung kvinne med \\ livstruende komplikasjoner til spiseforstyrrelse.
}

Se kommentar side 361 og kunnskapsprøve på www.tidsskriftet.no/quiz

\section{Arne Stokke*}

arnestokke@hotmail.com

Anestesiavdelingen

Nordlandssykehuset Bod $\varnothing$

8092 Bodø

\section{Joar Julsrud}

Medisinsk avdeling

Universitetssykehuset Nord-Norge

Troms $\varnothing$

\section{Anette Fosse}

Legesenteret

Mo i Rana

\section{Erik Waage Nielsen}

Anestesiavdelingen

Nordlandssykehuset Bodø

og

Institutt for klinisk medisin

Universitetet i Troms $\varnothing$

\author{
* Nåværende adresse: \\ Barneavdelingen \\ Nordlandssykehuset Bodø \\ 8092 Bod $\varnothing$
}

En kvinne i 20-årene var blitt behandlet for alvorlig anoreksi, hypokalemi og depresjoner i to-tre år. Hun hadde kastet opp daglig siste år. Et halvt år etter sykdomsdebuten var hun blitt tvangsinnlagt i psykiatrisk sykehus pga. fallende vekt. Hun ble utskrevet etter fire måneder og fikk tett oppfølging i et samarbeid mellom fastlege, psykatrikontor og psykiatrisk sykehus. Oppfølgingen innbefattet konsultasjoner flere ganger $i$ uken, med blodprøver, EKG, blodtrykksmåling, terapigrupper, psykologtimer og besøk fra kommunens psykiatrikontor. Behandlingsteamet tok også i bruk tekstmeldinger på mobiltelefon og videomøter. Etter noen måneder endret teamet ved psykiatrisk sykehus konsultasjonene til todagers seanser pga. lang og slitsom reisevei for kvinnen. Hun var hos fastlege 1-2 ganger i uken og diskuterte kaliumgrense, vektgrense og det å få slippe veiing og EKG.

Fastlegen oppfattet kvinnens ønske om ikke å overholde grensene for vekt og kaliumnivå som en form for selvskading. I perioder kuttet hun seg i huden før hun skulle veies. Det ble i samråd med psykiater startet behandling med antipsykotikumet quetiapin.

Regelmessig EKG-undersøkelse ble avsluttet i samråd med kardiolog fordi pasienten motsatte seg undersøkelsen. Hun slapp også jevnlig veiing i perioder av samme grunn, men kaliumverdiene ble fulgt regelmessig. Så gikk vekten synlig ned, og de siste tre måneder ble veiing hver annen uke gjeninnført. Det var hele tiden store utfordringer med å bygge tillit og opprettholde en holdbar terapeutisk relasjon - som er helt nødvendig for oppfølging og behandling. Erfaringene fra innleggelser både i somatisk og psykiatrisk sykehus var ikke gode, oppholdene hadde ikke ført til bedring. Dette bidro til at man i det lengste unngikk å gå til tvangsinnleggelse, selv om de somatiske kontrollverdiene (BMI, elektrolytter) i lang tid var i grenseland.

Det ble satt en vektgrense tilsvarende en kroppsmasseindeks (BMI) på $14 \mathrm{~kg} / \mathrm{m}^{2}$. Lavere verdier enn dette skulle føre til innleggelse $i$ psykiatrisk avdeling, ev. ved tvang. Kaliumverdiene var i denne perioden 2,4-2,6 $\mathrm{mmol} / \mathrm{l} \mathrm{(3,5-5,0} \mathrm{mmol/l).} \mathrm{Pasienten} \mathrm{fikk} \mathrm{økt}$ kaliumtilskudd per os og i perioder også kalium intravenøst i sykehus. BMI holdt seg like over $14 \mathrm{~kg} / \mathrm{m}^{2}$. Hun forsøkte å jukse under veiingen ved å ha vekter tapet til lårene og skjult i $\mathrm{BH}$-en.

Tvangsinnleggelse ble vurdert på ny, men situasjonen var vanskelig. I dialog mellom pasient og behandlerteam ble innleggelse vurdert som uhensiktsmessig slik totalsituasjonen var.

Da fastlegen var tilbake etter ferie, virket pasienten sliten. Hun uttrykte ønske om å gjøre noe konstruktivt med sin situasjon og hadde vært i kontakt med psykiatrisk sykehus. Det var blitt avtalt forvernsamtale med tanke på frivillig innleggelse noen uker senere. På bakgrunn av dette «forhandlet» hun seg frem til utsettelse av veiingen til neste konsultasjon. Om kvelden to dager senere ringte hun fastlegen og fortalte at hun følte seg svimmel og dårlig - og ble øyeblikkelig innlagt i lokalsykehuset. Hun var da slapp og klaget over hjertebank. Arteriell blodgass-måling viste $\mathrm{pH} 7,62(7,35-7,45)$, $\mathrm{pCO}_{2} 5,51 \mathrm{kPa}(4,70-6,00 \mathrm{kPa})$, baseoverskudd (BE) 19,4 mmol/l (-3-+3) og bikarbonat 43,4 mmol/l (22,0-26,0 mmol/l). Natriumnivået var $115 \mathrm{mmol} / \mathrm{l}(135-145 \mathrm{mmol} / \mathrm{l})$ og kaliumnivet $2,3 \mathrm{mmol} / \mathrm{l} \quad(3,5-5,0 \mathrm{mmol} / \mathrm{l})$. Kvinnen fikk tonisk-kloniske kramper i akuttmottaket.

Krampeanfallet ble vurdert som epileptisk og kupert med diazepam. Kvinnen ble oppfattet som hypovolemisk og i dårlig ernæringstilstand, med alvorlig hyponatremi og hypokalemi. Man antok at hypokalemien og den metabolske alkalosen i hovedsak skyldtes hyppige episoder med oppkast. Ved oppkast tapes hydrogen- og kloridioner. Konsentrasjonen av natrium og kalium i ventrikkelsekret er lav.

Når parietalcellene secernerer hydrogenioner, dannes ekvimolar mengde bikarbonationer. Konsentrasjonen av bikarbonat i ekstracellullær væske øker. Så lenge den glomerulære filtrasjonen opprettholdes og det ikke er vesentlig hypovolemi, vil glomeruli filtrere mer bikarbonat og det vil bli skilt ut bikarbonat i urinen (alkalisk urin). Bikarbonat i urinen (negativ elektrisk ladning) må ledsages av kation (positiv elektrisk ladning), fordi alle ekskreter må være elektrisk nøytrale. Når natrium når samlerørene sammen med bikarbonat, aktiveres natriumreabsorpsjon, som stimulerer til økt kaliumsecernering. Det tapes relativt lite natrium og mye kalium. Ved gjentatte brekninger utvikles hypovolemi og glomerulær filtrasjonshastighet faller. Sympatikus og reninangiotensin-aldosteron-systemet aktiveres. Nå øker reabsorpsjonen av natrium og bikarbonat i proksimale tubulus og samlerør.

Til tross for alkalose i serum er urinen sur (paradoks aciduri), noe som forsterker pasientens metabolske alkalose. Det utvikles kaliumunderskudd. Kaliumioner flyttes over cellemembranen fra det intracellullære til det ekstracellullære væskerom, mens hydrogenioner flyttes motsatt vei. Dette bidrar til å generere bikarbonat ekstracellullært, og cellene blir sure. Metabolsk acidose intracellulært og metabolsk alkalose ekstracellulært er typisk ved hypokalemi. Intracellullær acidose gir økt secernering av ammoniumioner 
i proksimale tubulus og øker secerneringen av hydrogenioner i samlerør $(1,2)$. Flere virkningsmekanismer bidrar således til alkalose og hypokalemi (fig 1, fig 2).

Pasienten ble flyttet til intensivavdelingen og fikk intravenøse væsker tilsatt kalium. Hun våknet raskt etter krampeanfallet og var klar og orientert. Så fikk hun på nytt tonisk-klonisk krampeanfall og ble gitt diazepam. Under anfallet hadde hun ventrikulær rytme som spontant slo om til sinusrytme (fig 3). Da hun to timer senere fikk nye kramper, hadde hun også ventrikulær rytme, som denne gang ble defibrillert til sinustrytme. Imidlertid vedvarte krampene på tross av at hun hadde fått diazepam, og hun ble intubert og respiratorbehandlet.

Ved alvorlige spiseforstyrrelser varierer tiårsdødsrisikoen i ulike studier mellom 0 og $20 \%$. En metaanalyse av 3006 pasienter innlagt for alvorlig spiseforstyrrelse viste en gjennomsnittlig tiårsmortalitet på 5,9\%. Omtrent halvparten av dødsfallene skyldtes somatiske komplikasjoner som hjerterytmeforstyrrelser, akutt hjertesvikt, hjerteinfarkt, reernæringssyndrom og hypoglykemi (3). I vårt tilfelle mistenkte vakthavende lege og de pårørende medikamentoverdosering, men medisindosettene var fulle. Det var ingen mistanker om annen forgiftning, og pasienten selv benektet dette.

De første blodgassundersøkelsene etter intubasjon viste $\mathrm{pCO}_{2}$ på 5,2-5,5 kPa, og pasienten ble forbigående mer stabil. Hun fikk fortsatt tilskudd av væske og kalium i form av $\mathrm{NaCl} 0,9 \%$ tilsatt $60 \mathrm{mmol} \mathrm{K} / 1000 \mathrm{ml}$ gitt med en hastighet på $100 \mathrm{ml} / \mathrm{t}$ og glukose $5 \%$ tilsatt $40 \mathrm{mmol} \mathrm{K} / 500 \mathrm{ml}$ med ukjent infusjonshastighet, men totalt sett ble det kun gitt $500 \mathrm{ml}$. Gjennom natten falt så likevel kaliumnivået til laveste verdi $1,7 \mathrm{mmol} / \mathrm{l}$, $\mathrm{pCO}_{2}$ var 3,92 kPa og $\mathrm{pH}$ var 7,83. Etter å ha vært stabil sirkulatorisk i seks timer fikk hun igjen ventrikulær rytme som spontant konverterte til sinusrytme med hyppige multifokale, ventrikulære ekstrasystoler. Episoder med ventrikulære arytmier tiltok frem mot morgenen.

Man hadde nå ingen sikker forklaring på at pasientens kaliumverdier gikk ned på tross av tilførsel av kalium intravenøst. Argininklorid for korrigering av alkalose var ikke tilgjengelig. Dette kunnet ha senket $\mathrm{pH}-$ verdien og således bidratt til å øke serumkaliumverdien. Et større sykehus ble kontaktet for overflytting.

Ledsager under transporten var en erfaren anestesiolog, som bevisst forsøkte å underventilere pasienten med håndventilering. Kapnografen fungerte ikke underveis pga. kalibreringsfeil. Ved ankomst i intensivavdelingen hadde pasienten flere ventrikkeltakykardier med tap av blodtrykk. Blodgass-

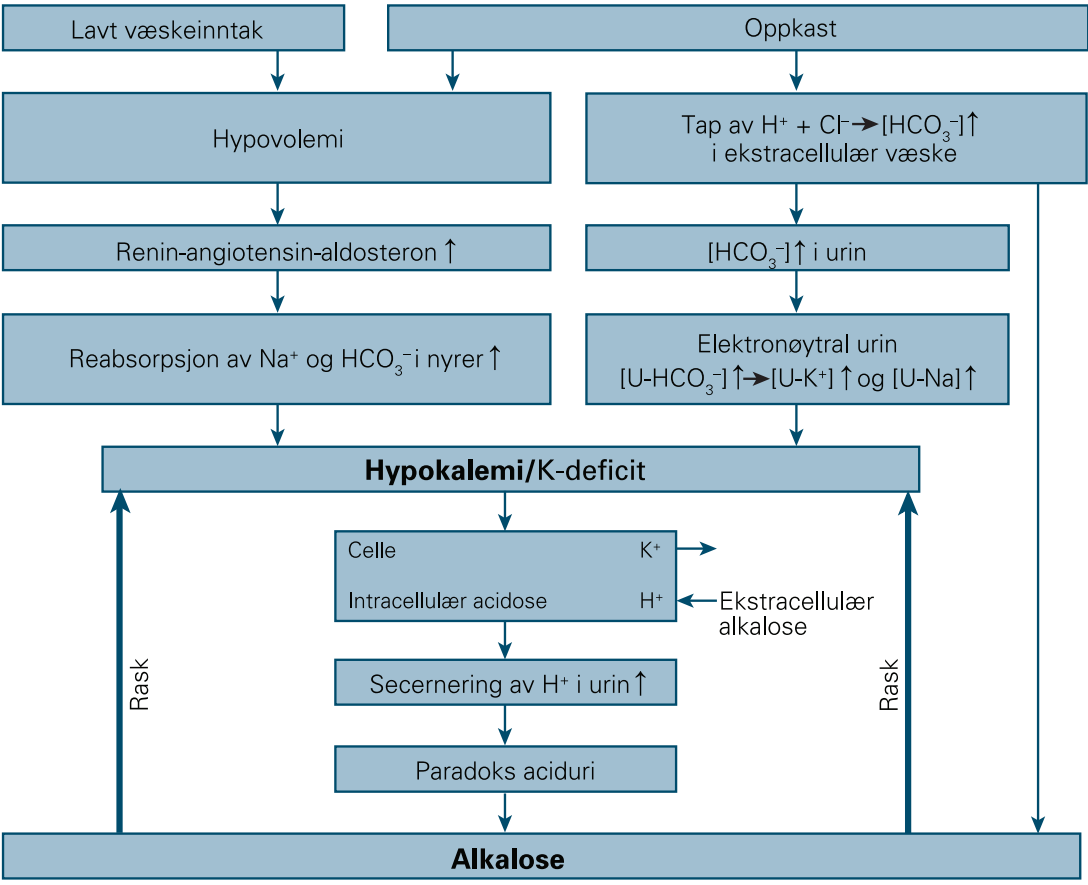

Figur 1 En forenklet oversikt over de komplekse mekanismene som medførte hypokalemi hos pasienten

måling viste $\mathrm{pH} 7,84(7,37-7,45)$ og $\mathrm{pCO}_{2}$ 3,46 kPa (4,3-5,7 kPa). QT-tiden var ca. 775 ms (fig 4). Ventrikkeltakykardien slo om til pulsgivende rytme ved prekordiale slag.

Man antok at den uttalte arytmitendensen skyldtes den ekstremt lave kaliumverdien, og behandlingen konsentrerte seg om dette $\mathrm{i}$ første omgang. Pasienten var blitt overventi-

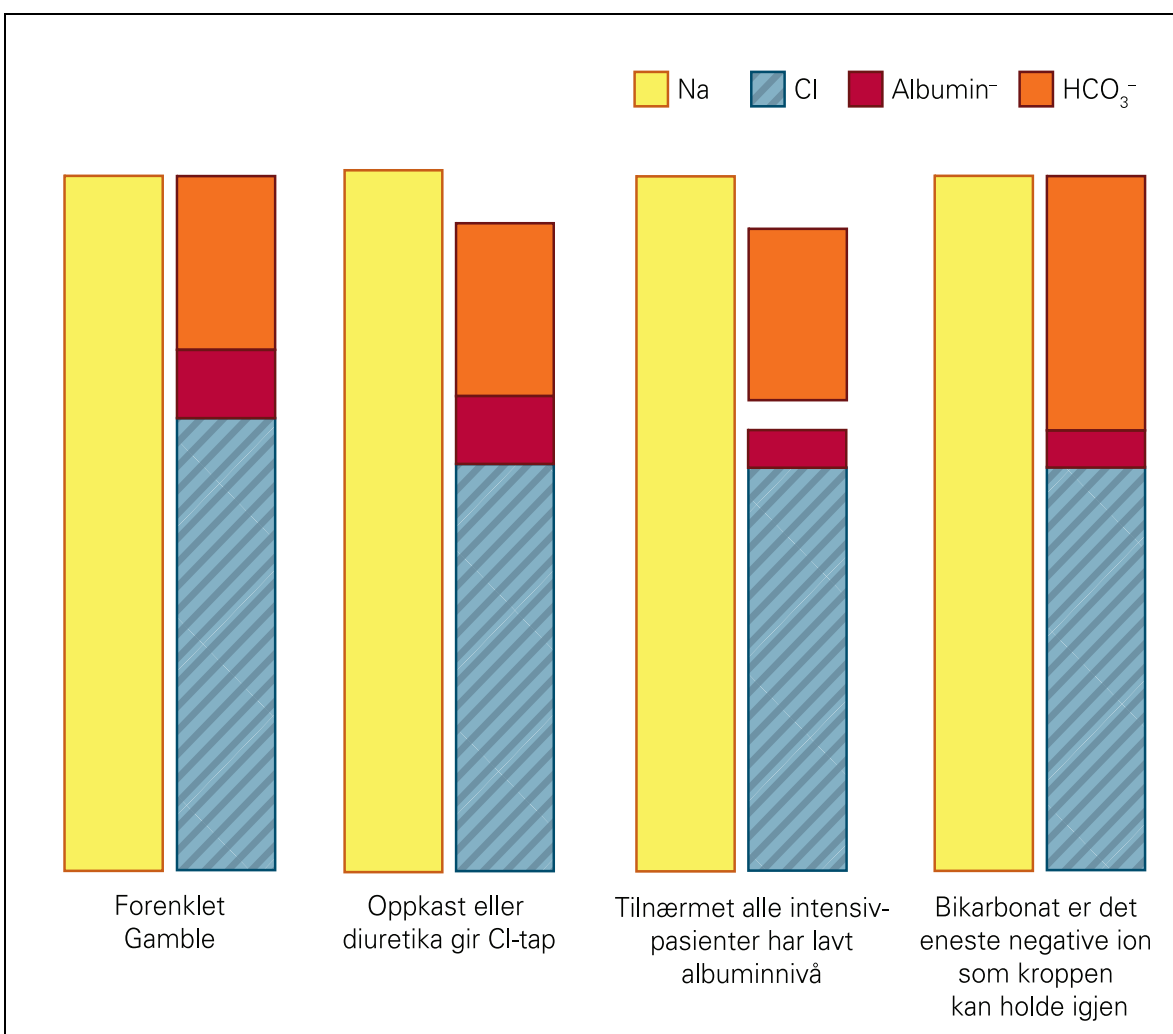

Figur 2 Diagrammet viser bl.a hvordan tap av klor loppkast) og albumin (anoreksi) medfører alkalose som følge av krav til elektronøytralitet i serum 


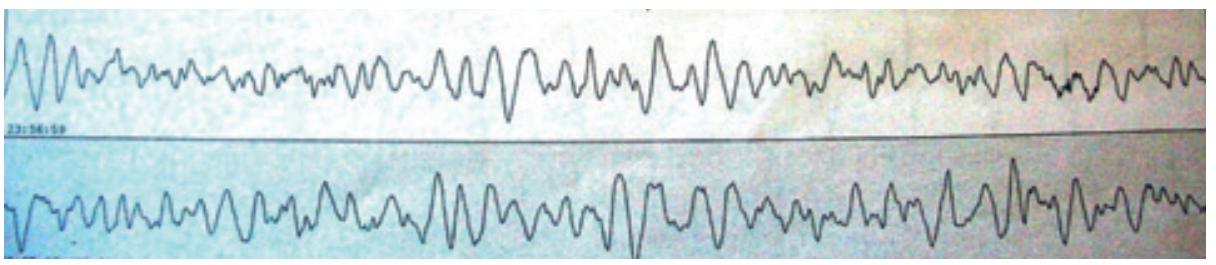

Figur 3 EKG-utskrift fra overvåkningsskop med økende og minkende amplitude som ved torsades de pointes

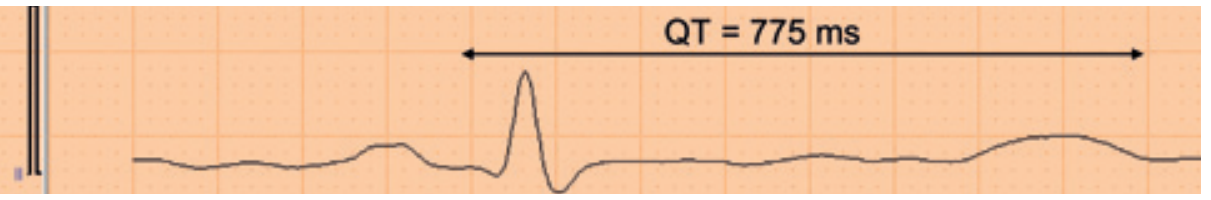

Figur 4 Betydelig forlenget QT-tid 0,775 s med korrigert verdi QTC 0,685 s (< 460 ms). Pasienten hadde tidligere normal QT-tid

lert før transport - og også under transporten - til tross for at anestesiologen bevisst hadde forsøkt å gjøre det motsatte. Grunnen til dette kan ha vært at hun var så mager at karbondioksidproduksjonen var svært liten. Det kan også skyldes at respiratorbehandlingen ble styrt etter $p \mathrm{CO}_{2}$-verdien og ikke etter $\mathrm{pH}$-verdien. Det er i så fall en svært vanlig feiloppfatning. Under senere narkose på operasjonsstuen måtte minuttvolumet på ventilatoren stilles så lavt som 3,0 1 (tidalvolum $250 \mathrm{ml}$ ) for å holde normal $\mathrm{pH}$-verdi. Det er 30-50\% av hva pasientens normalvektige jevnaldrende ville trenge.

Den høye $\mathrm{pH}$-verdien er den viktigste årsaken til at hypokalemien utviklet seg til en livstruende tilstand. Under komplekse kliniske tilstander kan effekten være vanskelig å beregne nøyaktig, men som isolert faktor gir en økning på $0,1 \mathrm{i}$ pH et fall i serum-kaliumnivå på ca. $0,5 \mathrm{mmol} / 1$.

Det ble gitt $100 \%$ oksygen fra respirator innstilt på 1-2 I minuttvolum. Så ble det startet infusjon av arginin-, kalium-og natriumklorid. Etter 20 minutter var $\mathrm{pH}$ 7,50. Kaliumverdien var 3,1 mmol/l etter 50 minutter. Ventrikulære ekstrasystoler og ventrikkeltakykardien avtok raskt. Pasienten ble ekstubert sju timer etter innkomst. Hun var uforandret mentalt.

\section{Diskusjon}

Vi beskriver en ung kvinne med alvorlige spiseforstyrrelser som var svært nær ved å dø av hjerterytmeforstyrrelser.

Pasienten tapte altså $\mathrm{H}^{+}$og $\mathrm{Cl}^{-}$i oppkast, mens både $\mathrm{Na}^{+}, \mathrm{K}^{+}$og $\mathrm{H}^{+}$ble tapt $\mathrm{i}$ urinen. Hun fikk intravenøs behandling med væske hvor både saltvann og glukose var tilsatt kalium. Dersom man i en situasjon med lav serum-kaliumverdi gir glukoseløsninger, kan kroppens egen insulinproduksjon stimuleres. Effekten kan da bli som ved et insulinglukose-drypp og gi fallende nivå av serumkalium.

Vi mener det var den akutte forverringen av hypokalemien som ga forlenget QT-tid.
Hyponatremien var sannsynligvis ikke dikan ha bidratt til forlenget QT-tid. Forlenget QT-tid ga torsades de pointes-ventrikkeltakykardi hos vår pasient. Denne type hjerterytmeforstyrrelse konverterer ofte til sinusrytme spontant, men kan gå over til ventrikkelflimmer - med dødelig utgang. Under arytmiene synker blodtrykket, det kan oppstå forbigående cerebral hypoksi og det kan utløses krampeanfall. Kramper hos anoreksipasienter forveksles ikke sjelden med epilepsi, og det er uvisst hvor mange som egentlig er arytmiutløst (4).

QT-tid måles fra begynnelsen av QRSkomplekset til slutten av T-bølgen. QT-intervallet varierer med hjertefrekvensen og kan korrigeres med Bazzets formel: QTc $=\mathrm{QT} /$ $\sqrt{\mathrm{R}-\mathrm{R}-\text { intervall. Hjertemuskelcellene repola- }}$ riseres i QT-tiden. Ved lav kaliumverdi i blodet forsinkes repolariseringen og inaktiveringen av de kanalene som kan gi for tidlig depolarisering. For tidlig depolarisering kan gi ventrikkeltakykardi (5). Det er angitt at QTctid over $500 \mathrm{~ms}$ medfører økt risiko for torsades de pointes (6). Vi tror ventrikkeltakykardien førte til de kortvarige krampeanfallene hos vår pasient, siden hun ble helt våken så snart hun fikk sinusrytme. Vi målte QT-tiden til 775 ms og QTc-tiden til 685 ms hos vår pasient. Normalverdien for QTc hos kvinner er $<460 \mathrm{~ms}$, ved verdier over dette frarådes oppstart av medikamenter som kan forlenge QTtiden $(3,6)$. Quetiapin er et slikt medikament (7). Vår pasient hadde imidlertid normal QTtid da quetiapinbehandlingen ble startet. Senere utviklet hun en rekke risikofaktorer for forlenget QT-tid, i tillegg til medisinen. Viktigst var hypokalemien, men alvorlig avmagring er en selvstendig risikofaktor for forlenget QT-tid uavhengig av kaliumnivå $(4,6,8)$. BMI-verdi under $15 \mathrm{~kg} / \mathrm{m}^{2}$ eller raskt vekttap gir også økt risiko for forlenget QT-tid (6). Autopsier av hjertemuskel fra anoreksipasienter har vist ekstrem atrofi og anatomisk remodellering (8). QT-tiden bør derfor måles regelmessig hos disse pasientene.

Protonpumpehemmer, som gjør at mindre rekte krampeutløsende, mens hypokalsemi saltsyre tapes ved oppkast, kan kanskje minske metabolsk alkalose og hypokalemi hos anoreksipasienter (9). Viktigst er det imidlertid å vurdere sykehusinnleggelse. Når anoreksi fører til hypokalemi, er det svært sannsynlig at pasienten kaster opp daglig og/ eller bruker laksantia eller diuretika (10). Anoreksien er da livstruende.

\section{Konklusjon}

Serum-kaliumverdien synker når $\mathrm{pH}$-verdien øker. Ekstrem alkalose kan derfor gi hypokalemi, forlenget QT-tid og livstruende ventrikkeltakykardi. Det er viktig å kjenne til den raske sammenhengen mellom $\mathrm{pH}$ og kalium og bl.a. derfor styre respiratoren etter $\mathrm{pH}$-verdi og ikke $p \mathrm{CO}_{2}$-verdi. Sammenhengen mellom $\mathrm{pH}$ og kalium kan utnyttes terapeutisk ved å underventilere pasienten. Dette øker karbondioksidnivået $\mathrm{i}$ blodet, senker $\mathrm{pH}$ raskt til normale verdier og øker kaliumnivået, noe som dermed stabiliserer hjerterytmen. På lengre sikt må korreksjon av hypokalemien også skje ved volumtilførsel, og glukoseløsninger bør da ikke benyttes. Medikamenter som forlenger QT-tiden bør unngås.

Anoreksi som fører til hypokalemi er livstruende, og pasienten bør behandles i sykehus.

Pasienten har gitt samtykke til at artikkelen blir publisert.

Oppgitte interessekonflikter: Ingen

\section{Litteratur}

. Ræder MG. Grunnbok i kirurgisk patofysiologi og intensivmedisin. Oslo: Ullevål universitetssykehus, 2007: 220.

2. Kassirer JP, Schwartz WB. The response of normal man to selective depletion of hydrochloric acid. Factors in the genesis of persistent gastric alkalosis. Am J Med 1966; 40: 10-8.

3. Frostad S. Somatisk utredning og behandling av spiseforstyrrelser. Tidsskr Nor Lægeforen 2004; 124: $2121-5$

4. Attanasio A, Argiriadou V. Sandri G et al. An anorexic woman with convulsive loss of consciousness. Syncope or epileptic fits? Int J Cardiol 2007; 116: e34-8

5. emedicine. Torsades de pointes. www.emedicine.com/med/topic2286.htm (29.12.2009).

6. Thorsen PJ, Berg A, Hoff PI et al. Risikofaktor for brå hjerted $ø$ d ved lang QT-syndrom. Tidsskr Nor Lægeforen 2006; 126: 2515-9.

7. Stöllberger C, Huber JO, Finsterer J. Antipsychotic drugs and QT prolongation. Int Clin Psychopharmacol 2005; 20: 243-51.

8. Vannacci A, Baronti R, Masini E et al. Anorexia nervosa and the risk of sudden death. Am J Med 2002: 112: 327-8.

9. Mehler PS, Linas S, Katoh T et al. Use of a proton pump inhibitor for metabolic disturbances associated with anorexia nervosa. N Engl J Med 2002; 347: 373-4.

10. Greenfeld D, Mickley D, Quinlan DM et al. Hypokalemia in outpatients with eating disorders. Am J Psychiatry 1995; 152: 60-3

Manuskriptet ble mottatt 11.1. 2009 og godkjent 27.7. 2010. Medisinsk redaktør Odd Terje Brustugun. 